\title{
1 Regulation of cGAS activity through RNA-mediated phase
}

\section{2 separation}

3 Silian Chen ${ }^{1 \#}$, Miao Rong ${ }^{1 \#}$, Yun $\mathrm{Lv}^{2}$, Deyu Zhu ${ }^{2 *}$, Ye Xiang ${ }^{1 *}$

$4 \quad{ }^{1}$ Center for Infectious Disease Research, Beijing Frontier Research Center for

5 Biological Structure \& Beijing Advanced Innovation Center for Structural Biology,

6 Department of Basic Medical Sciences, School of Medicine, Tsinghua University,

$7 \quad$ Beijing 100084, China.

$8{ }^{2}$ Department of Biochemistry and Molecular Biology, School of Basic Medical

9 Sciences, Cheeloo College of Medicine, Shandong University, Jinan 250012, China.

$10 \quad$ \#Contributed equally to this work.

$11{ }^{*}$ To whom correspondence should be addressed: D.Z.: zhudeyu@ sdu.edu.cn, Tel:

12 +86-531-88382092-416; Y.X.: yxiang@mail.tsinghua.edu.cn, Tel: +86-10-62772587 


\section{Abstract}

sensor that functions in the innate immune system. Upon binding dsDNA in the cytoplasm, cGAS and dsDNA form phase-separated aggregates in which cGAS catalyzes synthesis of 2'3'-cyclic GMP-AMP that subsequently triggers a STING-dependent, type I IFN response. Here, we showed that cytoplasmic RNAs, especially tRNAs, regulate cGAS activity. We discovered that RNAs did not activate cGAS but rather promoted phase separation in vitro. In cells, cGAS colocalized with RNAs and formed phase-separated granules even in the absence of cytoplasmic dsDNA. An Opti-prep gradient analysis of cell lysates showed that the endogenous cGAS was associated with cytoplasmic RNAs in an aggregative form. Further in vitro assays showed that RNAs compete for binding of cGAS with dsDNA and inhibit cGAS activity when the dsDNA concentration is high and promote the formation of phase separations and enhance cGAS activity when the dsDNA concentration is low. Thus, cytoplasmic RNAs regulate cGAS activity by interfering with formation of cGAS-containing aggregates. 


\section{Introduction}

Recognition of pathogen-derived nucleic acids by protein sensors allows the innate immune system to sense infection and initiate host defense mechanisms (1-3). The cyclic GMP-AMP synthase (cGAS) is the primary cytosolic double-stranded DNA (dsDNA) sensor in mammalian cells (4-7). Upon binding to dsDNA, cGAS undergoes conformational changes that activate its ability to catalyze synthesis of a noncanonical 2'3' cyclic-GMP-AMP dinucleotide (2’3'-cGAMP) that triggers type I interferon production through the endoplasmic reticulum membrane protein STING (also known as TMEM173, MPYS, MITA, and ERIS) (8-13). cGAS binds dsDNA in a sequence-independent manner (14-20). Abnormal activity of cGAS can lead to disease such as Aicardi-Goutières syndrome (21). cGAS activity is regulated by degradation or modification of the enzyme through ubiquitination, SUMOylation, phosphorylation, or glutamylation (22-25). A recent report suggests that cGAS activity is also regulated by the formation of phase-separated aggregates upon dsDNA engagement, which confine the activated cGAS to a particular location (26).

Previous studies indicated that a variety of parameters, including the concentration and length of the dsDNA, influence sensitivity of cGAS-mediated detection of cytosolic DNA $(27,28)$. However, cellular cGAS activity is not well explained by current structural and biophysical models $(26,28)$.

Here we showed that cGAS activity is regulated through RNA-mediated phase separation. We found that cGAS forms phase-separated granules with RNAs as well as dsDNA. Aggregation with cytoplasmic RNAs, especially tRNAs, promotes enzyme 
activity of cGAS at low concentrations of dsDNA but inhibits cGAS enzyme activity when high concentrations of dsDNA are present. Thus, RNA plays a novel and important role in regulating cGAS activity.

\section{DNA- and RNA-induced phase separation of cGAS}

We observed the formation of phase-separated granules soon after mixing the recombinant full-length human cGAS (FL-hcGAS) with a 45-bp double stranded interferon stimulatory DNA (ISD) (Figure S1A). Our results are consistent with the recently published work (26). In addition to dsDNA, previous studies showed that cGAS can bind RNAs, single-stranded DNAs (ssDNAs), and RNA-DNA hybrids (29-31). We also observed that the ssDNA without complementary regions can induce the formation of phase-separated granules when incubated with FL-hcGAS (Figure S1B). However, activation of FL-hcGAS was not observed when the ssDNAs had no complementary regions (Figure S1C). Short dsDNAs with one or more ssDNA arms induced strong phase separations of FL-hcGAS and activated the enzyme (Figure S2).

We next performed similar assays using total RNA extracted from HeLa cells. tRNAs are abundant in cytoplasm with an estimated concentration of approximately $1.2-1.8 \mathrm{mg} / \mathrm{mL}$ in mammalian cells and up to $20 \mathrm{mg} / \mathrm{mL}$ in yeast cells $(32-34)$. Phase-separated granules were observed when FL-hcGAS was mixed with yeast tRNA and total RNA from HeLa cells over a wide RNA concentration range, although activation of FL-hcGAS was not detected (Figure 1). Phase separation of FL-hcGAS was observed after DNase treatment of the RNA preparation and in presence of a 
large amount of BSA (Figure S3); the later mimics the crowded environment in the cytoplasm. The binding of RNAs to FL-hcGAS was estimated using an electrophoretic mobility shift assay, and the results showed that RNA bound cGAS with a similar affinity as that of dsDNA (Figure S4), which is consistent with previous studies (29).

\section{RNA induces phase-separation of cGAS in cells}

The concentration of RNAs, including tRNA and mRNA, in cytoplasm is much higher than is the concentration of DNA, probably even under abnormal conditions such as when cells are infected by viruses $(35,36)$. To test the hypothesis that cGAS forms phase-separated granules with RNA in the absence of DNA, we over-expressed hcGAS as a C-terminal fusion with the fluorescent tag YFP in the HEK293T cells. The YFP-hcGAS gene was controlled under a doxycycline-inducible promoter and was integrated in the cell genome. Confocal microscopy revealed that a portion of the cells with the YFP signals had phase-separated granules in the cytoplasm (Figure 2A). Staining of the cells with Hoechst 33342 and pyronin Y, which as previously described stain DNA and RNA, respectively (37), showed that the YFP-hcGAS colocalized with cytoplasmic RNAs, especially in the granules of YFP-hcGAS (Figure 2A). In vitro assays showed that dsDNAs and RNAs in the cGAS-containing aggregates are differentially stained by using the combination of the two dyes (Figure S5).

The interactions between cGAS and RNAs in a cytoplasmic extract of Hela 
108

cells were analyzed using an Opti-prep gradient (Figure 2B). There were five major bands in the gradient after centrifugation (Figure 2C). hcGAS was detected in fractions from each of these bands by western blot with a cGAS-specific antibody. The endogenous cGAS proteins was located mainly in band 5. Band 5 was sensitive to RNase but not DNase (Figure 2C \& 2D). Sequencing of the RNA in band 5 showed high numbers of reads for rRNAs and tRNAs (Figure S6), consistent with the abundance of different RNAs in cells (33). In the control gradient loaded with purified FL-hcGAS, the FL-hcGAS signals were detected by western blot mainly in fractions 1 and 2, near the top of the gradient (Figure 2C \& 2D). These results indicate that endogenous hcGAS associates with RNAs in cells prior to sensing cytoplasmic dsDNAs, which are usually not present in the cytoplasm.

\section{dsDNA replaces RNA in preformed phase-separated granules}

It was previously shown that molecules in the phase-separated granules are in dynamic equilibration with the molecules in solution (38). We observed that when Cy5-labeled ISD (Cy5-ISD) was transfected into HEK293T cells, the Cy5-ISD was eventually incorporated into the preformed granules of hcGAS-YFP (Figure 2E). As the electrophoretic mobility shift assays showed that the binding affinity of RNAs for hcGAS was comparable to that of dsDNA, in these cells where phase-separated granules exist prior to transfection, the transfected Cy5-ISD may replace RNA molecules in the granules.

To verify this, we performed in vitro assays with the 
fluorescein-5-thiosemicarbazide-labeled tRNA (FTSC-tRNA). Different amounts of ISD were added to solutions containing the preformed FTSC-tRNA-cGAS granules, and then the granules were separated from the solution by centrifugation and the signal due to FTSC-tRNA was measured in the supernatants (Figure 3A). As the concentration of the dsDNA was increased, the FTSC-tRNA signal increased in the supernatant until a plateau was reached (Figure 3B). This is indicative of a gradual substitution of the tRNAs by the dsDNAs until a dynamic equilibration was reached. Similarly, when granules were preformed from ISD and hcGAS, we observed a concentration dependent substitution of the dsDNAs by tRNAs (Figure 3C). Analyses by confocal microscopy also demonstrated that the nucleic acid component of the granules is in dynamic equilibrium (Figure 4).

Long dsDNAs such as ISD, 380-bp dsDNA and herring testis DNA displaced the tRNA in the phase-separated granules even at a low concentration of $0.025 \mathrm{mg} / \mathrm{mL}$ (Figure 3B \& Figure 4). In contrast, 14-bp and 20-bp dsDNAs, which bound to cGAS but did not induce the formation of aggregates (Figure S7), did not displace the tRNA (Figure 3B). A Y-form DNA, which is a 14-bp duplex with unpaired GGG at the termini, a structure previously shown to activate cGAS (39), induced the formation of the phase separations and also displaced tRNA from granules (Figure S7 and Figure 3B).

\section{tRNA-induced phase separation regulates cGAS activity}

Since hcGAS is not activated by binding to RNA, we reasoned that the 
competitive binding of RNAs to hcGAS should have a negative impact on the dsDNA-dependent activation of the enzyme. We measured the hcGAS activity with or without tRNA and showed that cGAS activity was significantly inhibited by tRNA when DNA concentration exceeded $0.05 \mathrm{mg} / \mathrm{mL}$ (Figure 5A). tRNA had little or no effect on cGAS activity when the DNA concentration was less than $0.01 \mathrm{mg} / \mathrm{mL}$, however (Figure 5A). At a high dsDNA concentration $(0.0544 \mathrm{mg} / \mathrm{mL})$, tRNA inhibited production of 2'3'-cGAMP catalyzed by hcGAS (Figure 5B), whereas at a low dsDNA concentration $(0.0068 \mathrm{mg} / \mathrm{mL}$ ) enzyme activity was stimulated (Figure 5C). Robust phase separation was observed at high DNA concentration (Figure 5D) but not at low DNA concentration (Figure 5E). The phase separation-related turbidity of the solution did not change significantly as a function of tRNA concentration with a high concentration of dsDNA (Figure 5F). However, the fluorescent signal due to FAM-labeled dsDNA was reduced within the granules upon addition of higher concentrations of tRNA (Figure 5D \& 5H). The phase separation related turbidity of the solution increased significantly as a function of tRNA concentration when the tRNA was added with a low concentration of dsDNA (Figure 5G). The fluorescent signal in the phase-separated granules remains constant. Thus, tRNA promotes the formation of phase separation when the dsDNA concentration is not high to induce aggregation (Figure 5E \& 5I). This tRNA mediated formation of phase separation promotes the activation of cGAS with even only a few dsDNA molecules (Figure 5C).

\section{Discussion}


177 activity to cytosolic dsDNA. At a low dsDNA concentration that is not enough to aggregates with cGAS that provide platforms for dsDNA-mediated cGAS activation.

When the cytoplasmic concentration of dsDNA is high enough to induce phase of cGAS activity. Our observation offers a reasonable mechanism by which cGAS sensitively detects cytosolic dsDNA but is modulated to ensure an appropriate provides an explanation of why short dsDNAs do not activate cGAS in cells, although they can active cGAS in vitro $(39,40)$. The abundances of tRNAs and mRNAs are

\section{Materials and methods}

\section{Protein expression and purification}


the GeneOptimizer algorithm (Thermo). The synthetic gene (Qinglan) was cloned into a modified pETDuet at a site designed to fuse a 10x His tag and a sumo tag at the $\mathrm{N}$-terminus of the protein. The pETDuet-hcGAS plasmid was transformed into $E$. coli BL21 Star (DE3) competent cells. The transformed cells were cultured in six 800-mL aliquots of $\mathrm{LB}$ at $37^{\circ} \mathrm{C}$ until the absorbance at $600 \mathrm{~nm}$ reached $\sim 0.6$. The cells and medium were cooled to $16{ }^{\circ} \mathrm{C}$, and $1 \mathrm{mM}$ IPTG was added to induce protein expression. The cells were harvested $16 \mathrm{~h}$ after the induction and were resuspended in $100 \mathrm{~mL}$ PBS buffer at pH 7.0 with $300 \mathrm{mM} \mathrm{NaCl}$. The resuspended cells were homogenized and the cell lysate was centrifugated at 20,000 g for $15 \mathrm{~min}$. The supernatant was applied to 4-mL Talon Metal Affinity Resin (Clontech, cat\# 635503). After washing with $30 \mathrm{~mL}$ wash buffer containing $20 \mathrm{mM}$ HEPES at pH 7.5, $150 \mathrm{mM}$ $\mathrm{NaCl}$, and $10 \mathrm{mM}$ imidazole, the resin was resuspended in $11 \mathrm{~mL}$ of buffer containing $20 \mathrm{mM}$ HEPES, pH 7.5, $150 \mathrm{mM} \mathrm{NaCl}$, and $0.1 \mathrm{mg} / \mathrm{mL}$ ULP1 and incubated at $4{ }^{\circ} \mathrm{C}$ for $12 \mathrm{~h}$ to remove the sumo tag. The hcGAS released from the resin was purified over a heparin column (GE Healthcare) to remove any dsDNA contamination and was further purified over a Superdex 75 size-exclusion column (GE Healthcare) using a running buffer containing $20 \mathrm{mM}$ HEPES, $\mathrm{pH} 7.5$, and $150 \mathrm{mM} \mathrm{NaCl}$.

\section{Fluorescence labeling of the tRNA, dsDNA, ssDNA, cGAS}

Yeast tRNAs (Solarbio, cat\# T8630) were labeled with FTSC as described by Qiu et al. (42). In brief, a solution containing $20 \mu \mathrm{L}$ tRNA (10 mg/mL) was mixed with $200 \mu \mathrm{L}$ of $0.25 \mathrm{M}$ sodium acetate. The mixture was diluted with $\mathrm{ddH}_{2} \mathrm{O}$ to a final 

buffer.

ISD and the 55-bp dsDNA were labeled by primer extension with the forward primer conjugated to FAM or Cy5 on the 5 ' terminus (Sangon). The ISD sequence is 5'-TACAGATCTACTAGTGATCTATGACTGATCTGTACATGATCTACA-3'. The 55-bp dsDNA sequence

CACT-3'. The 380-bp dsDNA was amplified from the SARS-CoV genome using a

232 forward primer with a 5' TAMRA label (Sangon). The primer sequences are forward AGCTTCTGGGCCAGTTCCTAG-3'. in $20 \mathrm{mM}$ HEPES, $\mathrm{pH} 7.5$, and $150 \mathrm{mM} \mathrm{NaCl}$ at a concentration of $1-5 \mathrm{mg} / \mathrm{mL}$ and 
(Millipore) with the $20 \mathrm{mM}$ HEPES, pH 7.5, and $150 \mathrm{mM} \mathrm{NaCl}$ as buffer.

\section{Observation of phase-separated aggregates}

tRNA, RNAs and FITC-labeled cGAS were mixed at the indicated concentrations and

FITC-labeled cGAS were observed by using laser scanning confocal microscopy with excitation set at $488 \mathrm{~nm}$ and emission filter set at 499-641 nm.

TAMRA-380 bp dsDNA) were added at the indicated concentrations. The samples

FTSC excitation: $488 \mathrm{~nm}$; FTSC emission filter: 491-535 nm; Cy5 excitation: $633 \mathrm{~nm}$; filter: $558-682 \mathrm{~nm}$. 
concentrations. The samples were prepared in $25 \mathrm{mM}$ Tris- $\mathrm{HCl}$ at $\mathrm{pH} 8.0,20 \mathrm{mM}$ $\mathrm{NaCl}, 5 \mathrm{mM} \mathrm{MgCl} 2,1 \mathrm{mM}$ ATP and $1 \mathrm{mM}$ GTP. Phase separation was observed by using laser scanning confocal microscopy with excitation set at $488 \mathrm{~nm}$ and emission filter set at $499-641 \mathrm{~nm}$.

\section{Stable cell line generation}

To generate the cell line that stably expresses doxycycline-inducible YFP-hcGAS, the sequence encoding YFP-hcGAS was cloned into the lentiviral vector pLVX-TetOne-Puro. A mixture of $2 \mu \mathrm{g}$ pLVX-TetOne-Puro-YFP-hcGAS, $1 \mu \mathrm{g}$ pMD2.G, and $1 \mu \mathrm{g}$ psPAX2 was transfected into the HEK293T cells using Lipofectamine 2000 (Thermo, cat\# 11668019) when cells were at $~ 70 \%$ confluence.

The cells were cultured in a 6-well plate with the DMEM medium (Thermo) and 10\% FBS (Gibco, cat\# 10091148) to generate the lentivirus. The medium containing lentiviruses was collected $60 \mathrm{~h}$ after the transfection, and the dead cell debris were removed by centrifugation. Polybrene was added to the solution at a final concentration of $0.8 \mu \mathrm{g} / \mathrm{mL}$ to enhance the lentiviral infection. The lentivirus was added to HEK293T cells cultured in a 6-well plate when cells were at 50-60\% confluence. Virus was replaced $12 \mathrm{~h}$ after infection with fresh DMEM medium containing $10 \%$ FBS. The cells were cultured for another $12 \mathrm{~h}$, and then puromycin was added to the medium at a final concentration of $2.5 \mu \mathrm{g} / \mathrm{mL}$. After passaging the cells three times in medium containing $2.5 \mu \mathrm{g} / \mathrm{mL}$ puromycin, the cells were maintained in the medium containing $2.5 \mu \mathrm{g} / \mathrm{mL}$ puromycin. 
Cell imaging

For RNA/DNA staining and imaging, YFP-hcGAS HEK293T cells were seeded on a coverslip. After 24 h, expression of YFP-hcGAS was induced by addition with 4\% polyformaldehyde in PBS and were washed with PBS after $15 \mathrm{~min}$. The cells were permeabilized with $0.5 \%$ Triton $\mathrm{X}-100$ in PBS for $15 \mathrm{~min}$, and then the cells were washed three times with PBS. PBS containing $2 \mu \mathrm{g} / \mathrm{mL}$ Hoechst 33342 and 4 $\mu \mathrm{g} / \mathrm{mL}$ pyronin $\mathrm{Y}$ (Amresco, cat\# 0207) was added to the cells to stain DNA and RNA, respectively. After $15 \mathrm{~min}$, coverslips were mounted on glass slides with Thermo Prolong Glass Antifade Mountant. After $2 \mathrm{~h}$ or longer, the slides were observed by confocal microscopy (Zeiss LSM 880). For each dye, excitation lasers and emission

filters were as follows: Hoechst 33342 excitation, 405 nm; Hoechst 33342 emission, 410-489 nm; YFP excitation, $514 \mathrm{~nm}$; YFP emission, 525-588 nm; pyronin $\mathrm{Y}$ excitation, $561 \mathrm{~nm}$; and pyronin Y emission, 625-758 nm. Phase-separated granules of cGAS and the 55-bp dsDNA, total RNA, or tRNA were observed as controls (Figure S5). were cultured in a four-chamber glass bottom dish (Cellvis, cat\# D35C4-20-1.5-N). 
tRNA displacement assays

The fluorescence signal of the free FTSC-tRNA in the supernatant was measured using a NanoDrop 3300 (Thermo Scientific). Release of the FAM-labeled ISD from the aggregates was measured in a similar way. The concentrations of the FTSC-tRNA and of the FAM-dsDNA had linear relationships with fluorescent signals in the range of 0.0125 to $0.2 \mathrm{mg} / \mathrm{mL}$ (Figure S8). The percentage of FTSC-tRNA displaced in the aggregates was calculated by using the following equation: $\mathrm{P}=(\mathrm{Fi}-\mathrm{F} 0) * 100 /(\mathrm{F}-\mathrm{F} 0)$. $\mathrm{P}$ : when DNA was not added. F: fluorescence signal of FTSC-tRNA without adding DNA and cGAS. The percentage of Cy5-ISD displaced in the aggregates was calculated by using a similar equation. 
supernatant (S2) was collected and centrifuged at 20,000 g to obtain the supernatant fraction S20 and the pellet fraction (P20). P20 was resuspended in an isotonic buffer (20 mM HEPES, pH 7.5, $250 \mathrm{mM}$ sucrose, $25 \mathrm{mM} \mathrm{KCl,} 5 \mathrm{mM} \mathrm{MgCl}_{2}$ ) containing $17.5 \%$ Opti-prep (Sigma, cat\# D1556). The resuspended P20 (500 $\mu \mathrm{L})$ was further fractionated over an Opti-prep density gradient after treatment with RNase $(20 \mu \mathrm{L}$ of $10 \mathrm{mg} / \mathrm{mL}$ RNase A, $5 \mu \mathrm{L}$ of $10 \mathrm{U} / \mu \mathrm{L}$ RNase I), DNase ( $25 \mu \mathrm{L}$ of $1 \mathrm{U} / \mu \mathrm{L}$ DNase I), or buffer for $30 \mathrm{~min}$ at $37{ }^{\circ} \mathrm{C}$. After further fractionation over an Opti-prep density gradient (isotonic buffer containing 35\%, 32.5\%, 30\%, 27.5\%, 25\%, 22.5\%, or $20 \%$ Opti-prep, from bottom to top, $500 \mu \mathrm{L}$ per layer, with resuspended P20 on the top of the gradient).

\section{In vitro analysis of cGAS activity}

In vitro enzymatic activities of cGAS were measured by monitoring the formation of the product 2'3'-cGAMP by using a HPLC system (SHIMADZU, LC-10A) equipped with LC-10AT pumps and an SPD-10AV ultraviolet detector. The strands of the 55-bp dsDNA were chemically synthesized: 5'-TCGATACAGATCTACTAGTGATCTATGACTGATCTGTACATGATCTACAAT 

2'3'-cGAMP visualized with $254 \mathrm{~nm}$ light. Each experiment was performed in triplicate.

\section{Figure Legends}

Figure 1. RNA mediates phase separation of cGAS. A. Fluorescent images of FITC-labeled full-length human cGAS (FITC-FL-hcGAS) incubated with yeast tRNA at the indicated $\mathrm{mg} / \mathrm{mL}$ ) and total RNA from HeLa cells at the indicated concentrations. C. TLC analysis of cGAMP, which is indicative of the activation of cGAS. The FL-hcGAS concentrations was $0.265 \mathrm{mg} / \mathrm{mL}$. Total RNA concentrations were $0.025,0.05,0.1,0.25$, and $0.85 \mathrm{mg} / \mathrm{mL}$. NC 
$\mathrm{mM} \mathrm{NaCl}$.

Figure 2. hcGAS associates with RNAs in cells. A. Hoechst 33342 and Pyronin Y staining

of HEK293T cells showing colocalization of the YFP-cGAS granules and RNAs.

Overexpression of the YFP-hcGAS was induced by doxycycline. B. A schematic diagram showing the extraction and fractionation procedure. To release the cytoplasm without disrupting the nuclear membrane, the cell membranes were disrupted in a hypotonic buffer by passing the cells through a $29 \mathrm{G}$ needle three times. The hypotonic buffer contained $10 \mathrm{mM}$

cytoplasm extract. D. Western blotting analysis of samples of Opti-prep gradient bands with and without DNase and RNase treatment. E. Real time observation showing the eventual incorporation of the lipofectamine 2000 transfected Cy5-ISD into a preformed granule of YFP-hcGAS in a HEK293T cell.

\section{Figure 3. Substitution of the tRNA in the cGAS-tRNA phase separations by dsDNA. A.}

A schematic diagram showing the methods used to quantify tRNA/dsDNA released from the 
394

fluorescence of FTSC-tRNA in the supernatant when DNA was not added. F: fluorescence of FTSC-tRNA without adding DNA and cGAS. The dsDNAs tested were ISD, 14 bp dsDNA, 20 bp dsDNA, 380 bp dsDNA, herring testis DNA (HT DNA) and Y-form DNA (a 14-bp dsDNA with unpaired GGG on each end). C. The percentage of Cy5-ISD released in the supernatant as measured by fluorescence spectroscopy. The yeast tRNA was used to trigger the release of the ISD from the phase separations of cGAS-ISD. The percentage of Cy5-ISD released from the aggregates was calculated by using the following equation: $\mathrm{P}=(\mathrm{Fi}-\mathrm{F} 0)^{*} 100 /(\mathrm{F}-\mathrm{F} 0) . \mathrm{P}$ : percentage of substituted Cy5-ISD. Fi: fluorescence of Cy5-ISD in the supernatant of each test. F0: fluorescence of Cy5-ISD in the supernatant when tRNA was not added. F: fluorescence of Cy5-ISD without adding tRNA and cGAS. All experiments were performed three times.

Figure 4. tRNA replacement by dsDNA in the cGAS-containing phase-separated granules observed by microscopy. A. Microscopy images of FTSC-tRNA in granules preformed with cGAS and indicated concentrations of FTSC-tRNA in the presence of indicated concentrations of ISD. B. Microscopy images of FTSC-tRNA in granules preformed with cGAS and indicated concentrations of FTSC-tRNA in the presence of indicated concentrations of a 380-bp dsDNA.

Figure 5. tRNA regulates cGAS activity. A. cGAS activity (as measured by cGAMP peak area) with or without $0.125 \mathrm{mg} / \mathrm{mL}$ tRNA at indicated concentrations of a 55-bp dsDNA. The inset is an expanded view of the region boxed in yellow. B. cGAS activity in presence of 

presence of $0.0068 \mathrm{mg} / \mathrm{mL}$ of $55-\mathrm{bp}$ dsDNA as a function of tRNA concentration. D.

418 Fluorescent and bright field photographs of phase-separated granules of FL-hcGAS and $0.0544 \mathrm{mg} / \mathrm{mL}$ of FAM-labeled 55-bp dsDNA at the indicated tRNA concentrations. E.

423 indicated tRNA concentrations measured at $395 \mathrm{~nm}$. G. Turbidities of samples of FL-hcGAS measured at $395 \mathrm{~nm}$. H. Fluorescent signals of the FAM-labeled 55-bp dsDNA in the supernatants of the samples of FL-hcGAS and $0.0544 \mathrm{mg} / \mathrm{mL}$ of FAM-labeled 55-bp dsDNA 55-bp dsDNA at the indicated tRNA concentrations. Each condition was evaluated in triplicate. and bright field photographs showing phase-separated granules of FITC-labeled FL-hcGAS

434 induced by the dsDNA referred to as ISD (for interferon stimulatory DNA), with the sequence 
and a $48 \mathrm{nt}$ ssDNA at the indicated concentrations. The $48 \mathrm{nt}$ ssDNA has the sequence 5'-AGAGAGAGAGAGAGAGAGAGAGAGAGAGAGAGAGAGAGAGAGAGAGAG-3'. C. TLC analysis for the presence of cGAMP, which is indicative of cGAS activation. The FL-hcGAS concentrations was $0.265 \mathrm{mg} / \mathrm{mL}$. ssDNA concentrations were $0.011,0.028,0.054$ and $0.111 \mathrm{mg} / \mathrm{mL}$. NC indicates negative control which has only the FL-hcGAS. The dsDNA ISD was tested at 0.055 and $0.111 \mathrm{mg} / \mathrm{mL}$ as positive controls. Samples were prepared in 20 $\mathrm{mM}$ HEPES at $\mathrm{pH} 7.5$ and $150 \mathrm{mM} \mathrm{NaCl}$.

\section{Supplemental Figure 2. Short dsDNAs with ssDNA arms promote phase separation and}

activation of cGAS. A. Sequences of short dsDNAs with ssDNA arms and dsDNA controls.

B. Photographs of samples of FL-hcGAS $(0.265 \mathrm{mg} / \mathrm{mL}, 4.4 \mu \mathrm{M})$ with indicated DNAs (2 $\mu \mathrm{M})$ taken with a differential interference contrast microscope. C. TLC analysis for cGAMP, which is indicative of the activation of cGAS, in the presence of short dsDNAs with ssDNA arms. The FL-hcGAS and DNA concentrations were $4.4 \mu \mathrm{M}$ and $2 \mu \mathrm{M}$, respectively. Samples were prepared in $20 \mathrm{mM}$ HEPES at $\mathrm{pH} 7.5$ and $150 \mathrm{mM} \mathrm{NaCl}$.

\section{Supplemental Figure 3. RNA mediates phase separation of cGAS. A. Upper: Bright field} photographs of samples of FL-hcGAS $(0.264 \mathrm{mg} / \mathrm{mL})$ and total RNA from HeLa cells at the indicated concentrations. Lower: Bright field photographs of samples of FL-hcGAS (0.264 $\mathrm{mg} / \mathrm{mL}$ ) and DNase I-treated total RNA at the indicated concentrations. B. Fluorescent images of FITC-labeled FL-hcGAS and total RNA from HeLa cells in presence of 100 
$\mathrm{mg} / \mathrm{mL}$ BSA; concentrations of FL-hcGAS and total RNA are indicated. Samples were prepared in $20 \mathrm{mM}$ HEPES, $\mathrm{pH} 7.5,150 \mathrm{mM} \mathrm{NaCl}$.

Supplemental Figure 4. RNA and DNA bind cGAS with similar affinity. Electrophoretic mobility shift analysis of ISD, 380-bp dsDNA, yeast tRNA and ssRNA in presence of FL-hcGAS. The nucleic acid concentration was $10 \mathrm{ng} / \mu \mathrm{L}$. The cGAS concentrations were 0 , $0.17,0.85,1.7,3.4,5.1,8.5$, and $13.6 \mu \mathrm{M}$.

\section{Supplemental Figure 5. Hoechst 33342 and pyronin $Y$ differentially stain dsDNA and}

RNA in the cGAS involved phase separations. Confocal microscopy images of FL-hcGAS incubated with 55-bp dsDNA, total RNA from HeLa cells, or yeast tRNA and stained with 2 $\mu \mathrm{g} / \mathrm{mL}$ Hoechst 33342 and $4 \mu \mathrm{g} / \mathrm{mL}$ pyronin Y. The FL-hcGAS concentrations was 0.2 $\mathrm{mg} / \mathrm{mL}$. 55-bp dsDNA, total RNA and yeast tRNA concentrations were both $0.1 \mathrm{mg} / \mathrm{mL}$.

\section{Supplemental Figure 6. Sequencing of RNA in the cGAS-containing fraction from}

cytoplasm. Two libraries were generated from band 5 from the Opti-prep gradient: one for non-coding RNA and one for mRNA sequencing. The histograms show the numbers of non-coding RNA sequencing reads. mRNA was also sequenced and the results showed coverage of most of the actively transcript genes.

\section{Supplemental Figure 7. Y-form DNA and 14-bp dsDNA mediate phase separation of}

FL-hcGAS. A. Sequences and structures of the, 14-bp dsDNA, 20-bp dsDNA and Y-form 
481

482

DNA. B. Fluorescent images of samples of FITC-FL-hcGAS and the 14-bp dsDNA at indicated concentrations. C. Corresponding bright field photographs of samples of FITC-FL-hcGAS and the 14-bp dsDNA at indicated concentrations. D. Fluorescent images of samples of FITC-FL-hcGAS and the Y-form DNA at indicated concentrations. E. Corresponding bright field photographs of samples of FITC-FL-hcGAS and the Y-form DNA.

\section{Supplemental Figure 8. Correlation of fluorescence signal (RFU) with concentration for}

\section{fluorophore labeled ISD and tRNA.}

Author Information: The authors declare no competing financial interests. Correspondence and requests for materials should be addressed to D.Y.Z.: zhudeyu@sdu.edu.cn; Y. X.: yxiang@mail.tsinghua.edu.cn.

Author Contributions: X.Y. designed the research; S.L.C., D.Z, M.R., Y. L., and X.Y. performed the experiments; S.L.C., D.Z., and X.Y. analyzed data and wrote the paper; all authors edited and approved the manuscript.

\section{Acknowledgements:}

We thank the Core Facility and the Cell Biology Facility of the Center of Biomedical Analysis, Tsinghua University for assistance with imaging. We thank Jiaying Yang for providing extracted total RNA from HeLa cells. This work was supported by funds from the

Ministry of Science and Technology of China (grant number: 2016YFA0501100), the 


\section{References}

511 1. R. Barbalat, S. E. Ewald, M. L. Mouchess, G. M. Barton, Nucleic acid recognition by the innate immune system. Annu Rev Immunol 29, 185-214 (2011).

2. S. Pandey, T. Kawai, S. Akira, Microbial sensing by Toll-like receptors and intracellular nucleic

13. W. Sun et al., ERIS, an endoplasmic reticulum IFN stimulator, activates innate immune

14. H. Yang, H. Wang, J. Ren, Q. Chen, Z. J. Chen, cGAS is essential for cellular senescence. Proc mitochondrial DNA. Cell 159, 1563-1577 (2014). 
16. M. J. White et al., Apoptotic caspases suppress mtDNA-induced STING-mediated type I IFN production. Cell 159, 1549-1562 (2014).

17. A. P. West et al., Mitochondrial DNA stress primes the antiviral innate immune response. Nature 520, 553-557 (2015).

18. L. Lau, E. E. Gray, R. L. Brunette, D. B. Stetson, DNA tumor virus oncogenes antagonize the cGAS-STING DNA-sensing pathway. Science 350, 568-571 (2015).

19. K. J. Mackenzie et al., cGAS surveillance of micronuclei links genome instability to innate immunity. Nature 548, 461-465 (2017).

20. H. Wang et al., cGAS is essential for the antitumor effect of immune checkpoint blockade.

21. D. Gao et al., Activation of cyclic GMP-AMP synthase by self-DNA causes autoimmune diseases. Proc. Natl. Acad. Sci. USA 112, E5699-E5705 (2015).

22. Q. Wang et al., The E3 ubiquitin ligase RNF185 facilitates the cGAS-mediated innate immune response. PLoS Path. 13, e1006264 (2017).

25. P. Xia et al., Glutamylation of the DNA sensor cGAS regulates its binding and synthase activity in antiviral immunity. Nat. Immunol. 17, 369-378 (2016).

26. M. Du, Z. J. Chen, DNA-induced liquid phase condensation of cGAS activates innate immune signaling. Science 361, eaat1022 (2018).

27. S. Luecke et al., cGAS is activated by DNA in a length-dependent manner. EMBO Rep 18, 1707-1715 (2017).

28. L. Andreeva et al., cGAS senses long and HMGB/TFAM-bound U-turn DNA by forming protein-DNA ladders. Nature 549, 394-398 (2017).

29. F. Civril et al., Structural mechanism of cytosolic DNA sensing by cGAS. Nature 498, 332-337 (2013).

30. Philip J. Kranzusch, Amy S.-Y. Lee, James M. Berger, Jennifer A. Doudna, Structure of Human cGAS Reveals a Conserved Family of Second-Messenger Enzymes in Innate Immunity. Cell Reports 3, 1362-1368 (2013).

33. A. F. Palazzo, E. S. Lee, Non-coding RNA: what is functional and what is junk? Front. Genet. 6,

34. M. Frenkel-Morgenstern et al., Genes adopt non-optimal codon usage to generate cell cycle-dependent oscillations in protein levels. Mol. Syst. Biol. 8, 572 (2012).

36. J. Russo, I. H. Russo, Techniques and methodological approaches in breast cancer research. (Springer, New York, 2014), pp. xvi, 287 p.

37. Z. Darzynkiewicz, G. Juan, E. F. Srour, Differential staining of DNA and RNA. Curr Protoc Cytom 
Chapter 7, Unit 73 (2004).

38. N. O. Taylor, M. T. Wei, H. A. Stone, C. P. Brangwynne, Quantifying Dynamics in Phase-Separated Condensates Using Fluorescence Recovery after Photobleaching. Biophys. J. 117, 1285-1300 (2019).

39. A.-M. Herzner et al., Sequence-specific activation of the DNA sensor cGAS by Y-form DNA structures as found in primary HIV-1 cDNA. Nat. Immunol. 16, ni.3267 (2015).

40. X. Li et al., Cyclic GMP-AMP Synthase Is Activated by Double-Stranded DNA-Induced Oligomerization. Immunity 39, 1019-1031 (2013).

593

41. M. Torrent, G. Chalancon, N. S. de Groot, A. Wuster, M. M. Babu, Cells alter their tRNA abundance to selectively regulate protein synthesis during stress conditions. Science Signaling 11, (2018). 
bioRxiv preprint doi: https://doi.org/10.1101/2020.09.27.316166; this version posted September 28, 2020. The copyright holder for this preprint (which was not certified by peer review) is the author/funder, who has granted bioRxiv a license to display the preprint in perpetuity. It is made available under aCC-BY-NC-ND 4.0 International license.
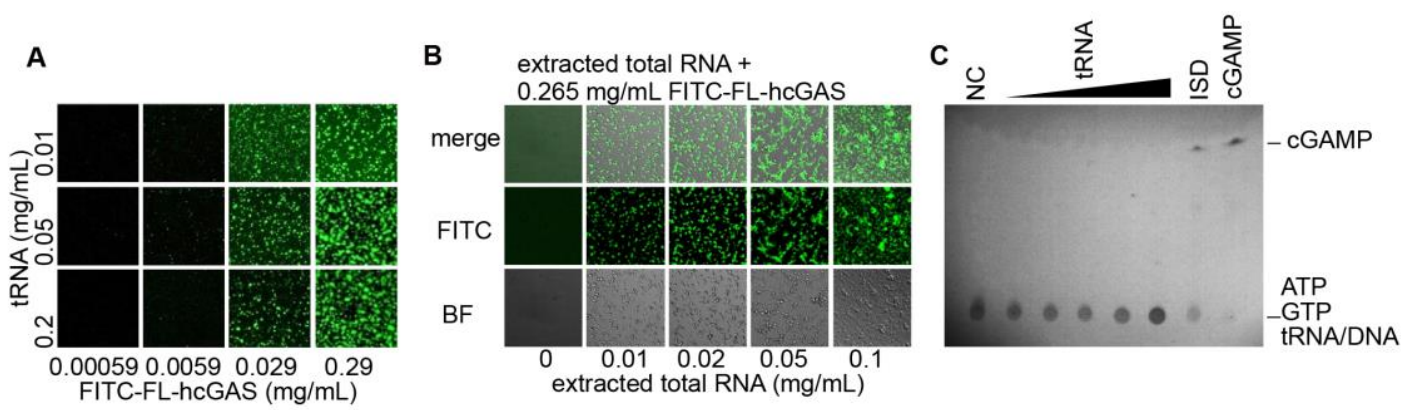

602 
bioRxiv preprint doi: https://doi org/10.1101/2020.09.27.316166; this version posted September 28, 2020. The copyright holder for this preprint (which was not certified by peer review) is the author/funder, who has granted bioRxiv a license to display the preprint in perpetuity. It is made available under aCC-BY-NC-ND 4.0 International license.

\section{Figure 2}

A
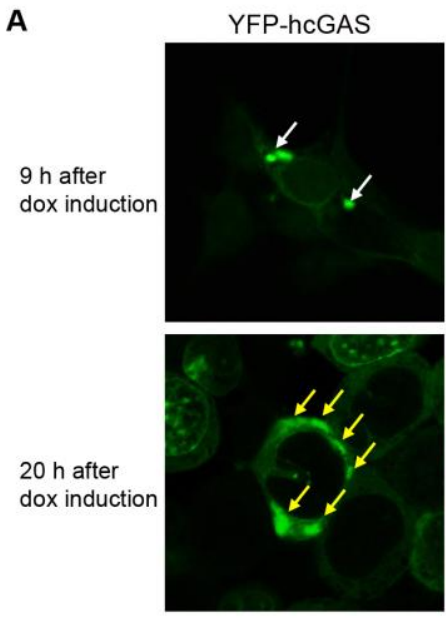

B

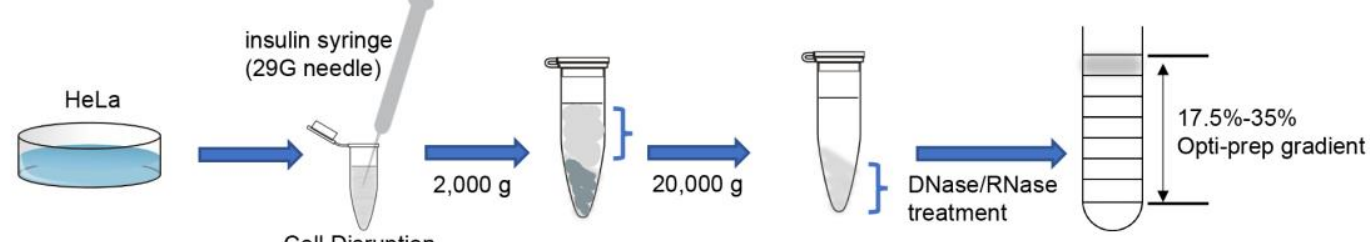

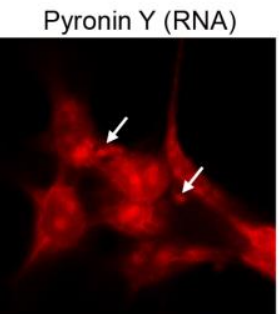

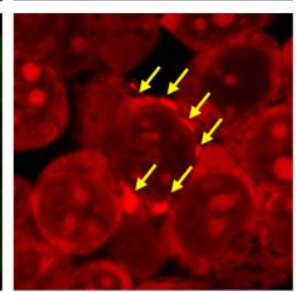

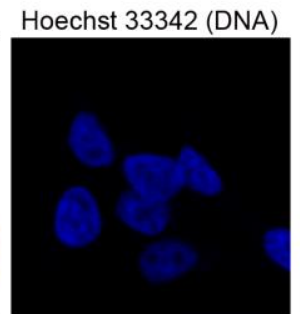
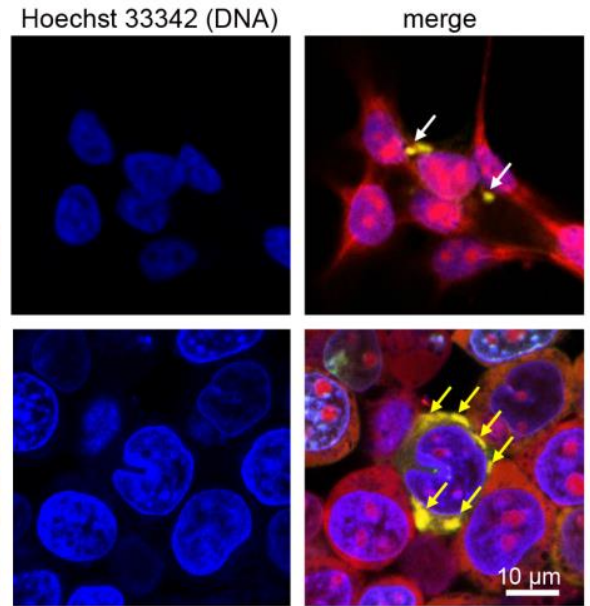
treatment

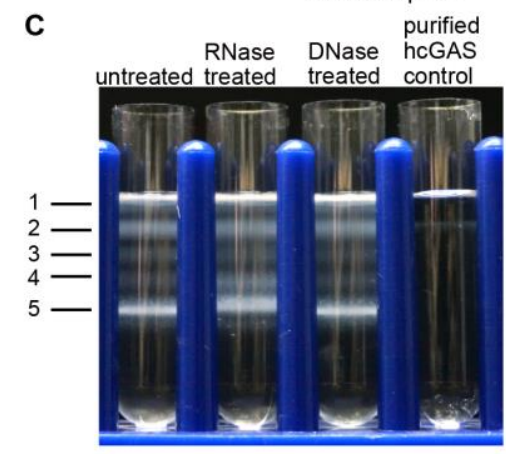

D

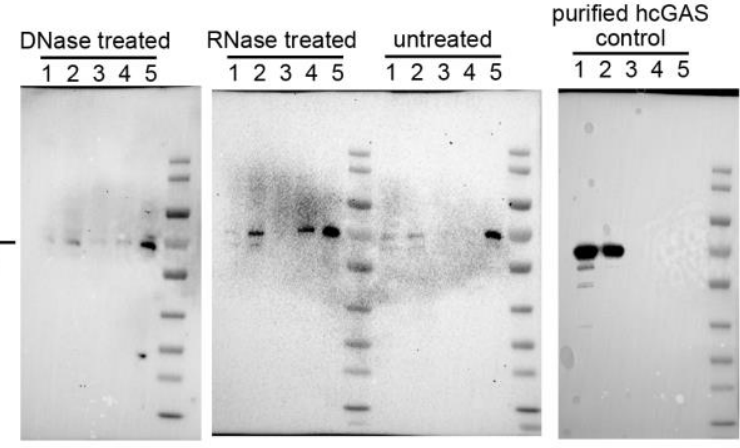

$E$
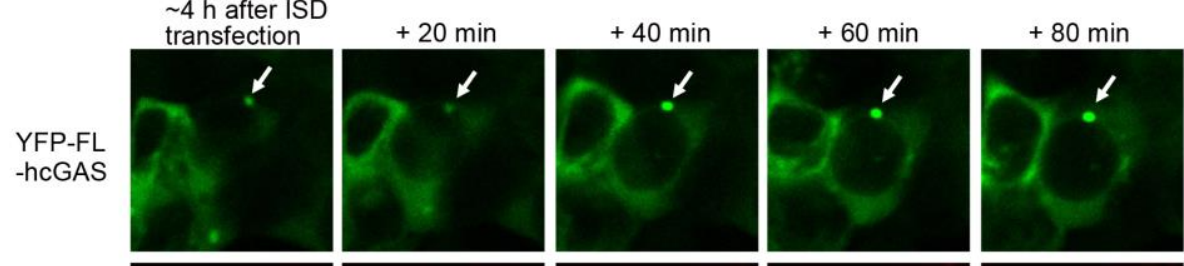

Cy5-ISD
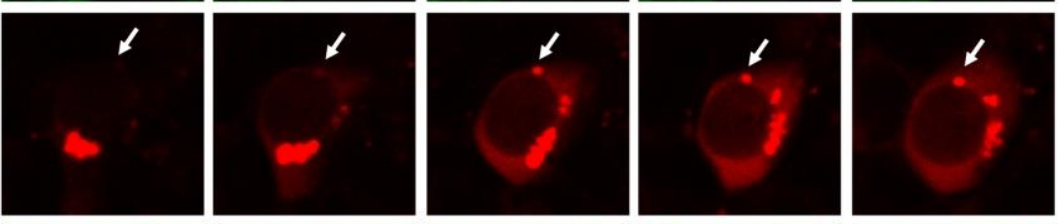

merge
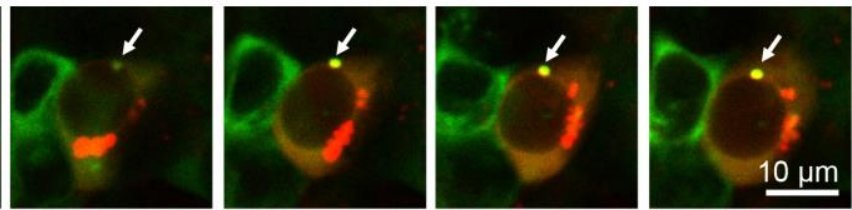
bioRxiv preprint doi: $\mathrm{https}: / / \mathrm{doi}$ org/10.1101/2020.09.27.316166; this version posted September 28, 2020. The copyright holder for this preprint (which was not certified by peer review) is the author/funder, who has granted bioRxiv a license to display the preprint in perpetuity. It is made available under aCC-BY-NC-ND 4.0 International license.

\section{Figure 3}

A

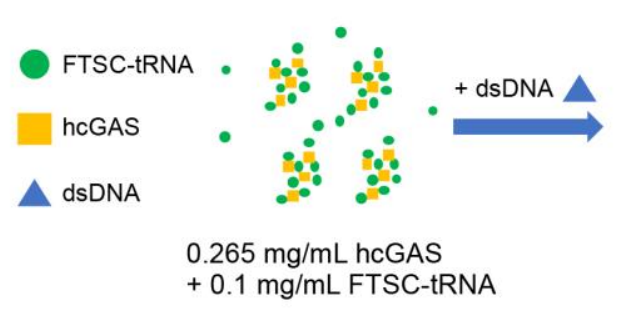

B

substitution of tRNA by dsDNA

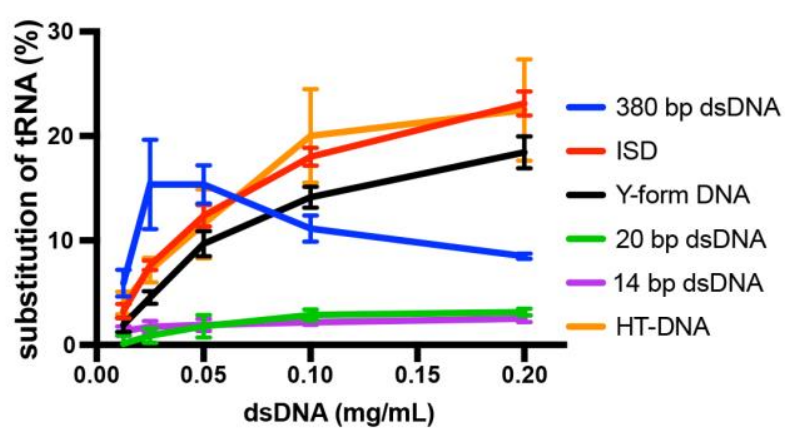

C

substitution of ISD by tRNA

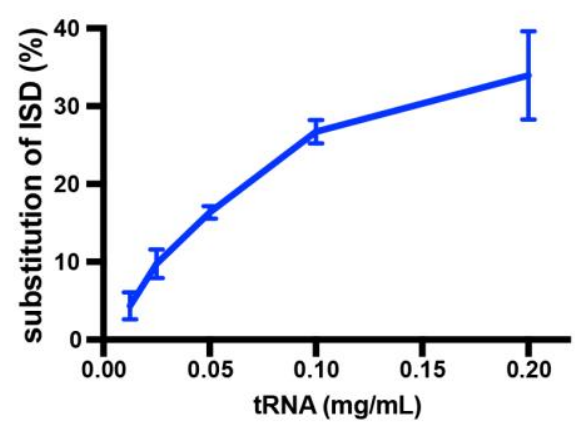


bioRxiv preprint doi: https://doi org/101101/2020.09 27 316166; this version posted September 28, 2020. The copyright holder for this preprint (which was not certified by peer review) is the author/funder, who has granted bioRxiv a license to display the preprint in perpetuity. It is made available under aCC-BY-NC-ND 4.0 International license.

\section{Figure 4}

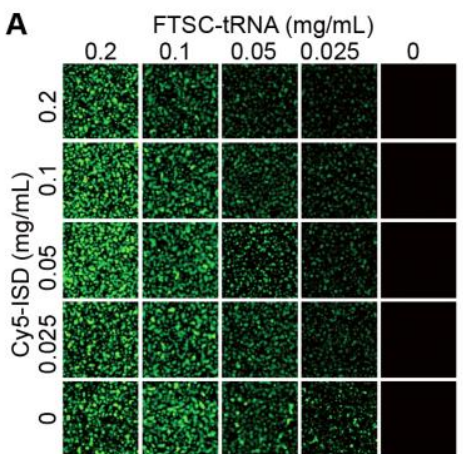

FITC Channel

B

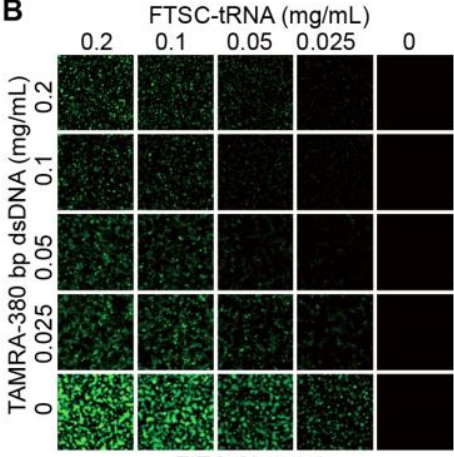

FITC Channel

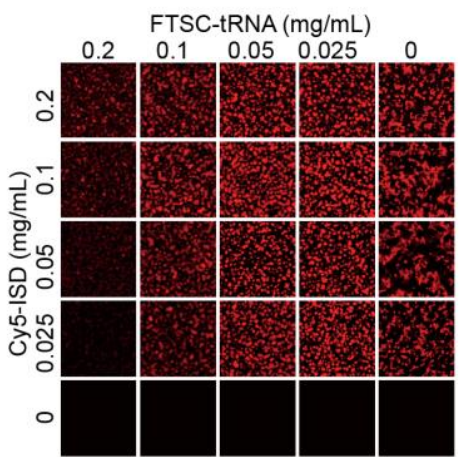

Cy5 Channel

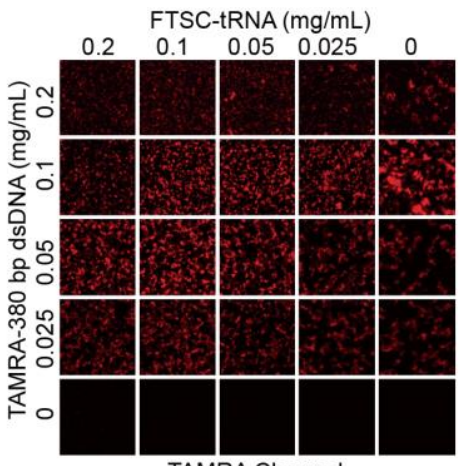

TAMRA Channel

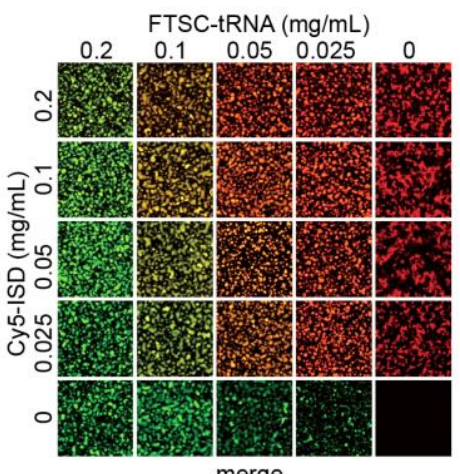

merge

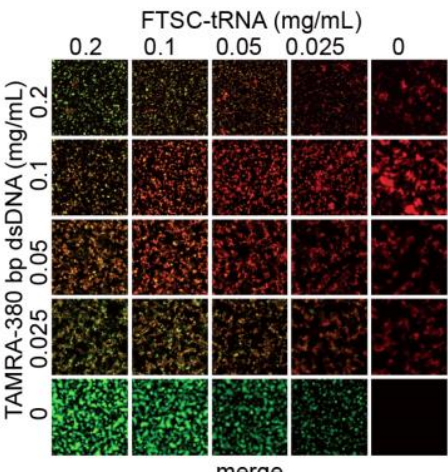


bioRxiv preprint doi: https://doi.org/10.1101/2020.09.27.316166; this version posted September 28, 2020. The copyright holder for this preprint (which was not certified by peer review) is the author/funder, who has granted bioRxiv a license to display the preprint in perpetuity. It is made available under aCC-BY-NC-ND 4.0 International license.

\section{Figure 5}

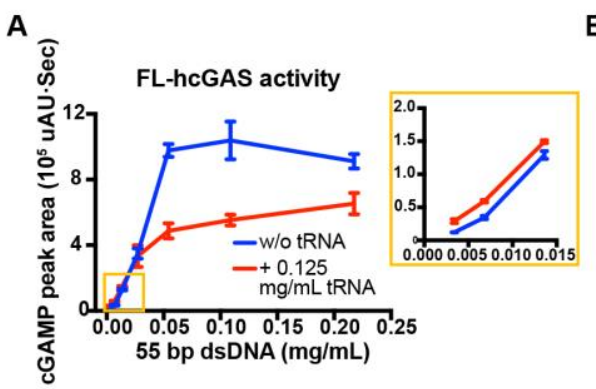

D tRNA + $0.0544 \mathrm{mg} / \mathrm{mL}$ FAM-55 bp dsDNA + $0.323 \mathrm{mg} / \mathrm{mL}$ FL-hcGAS
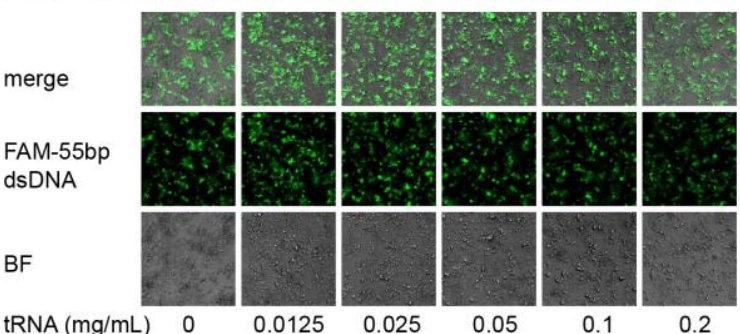

E tRNA + $0.0068 \mathrm{mg} / \mathrm{mL}$ FAM-55 bp dsDNA + $0.323 \mathrm{mg} / \mathrm{mL}$ FL-hcGAS

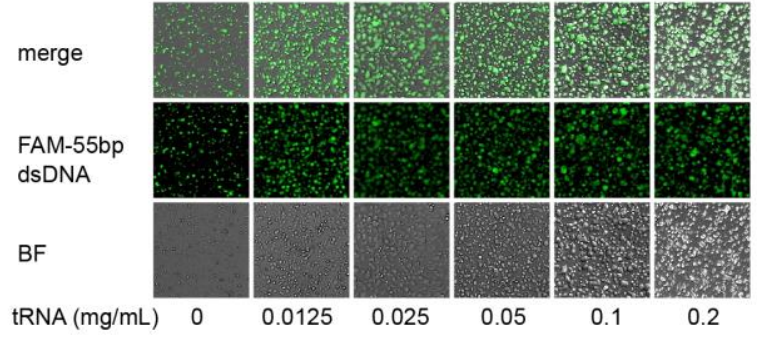

H

FAM-55 bp dsDNA (high concentration)

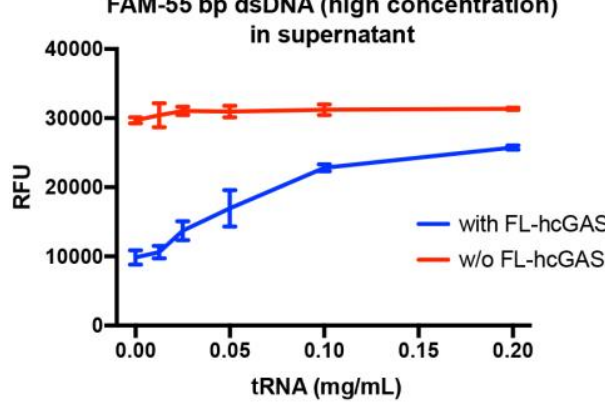

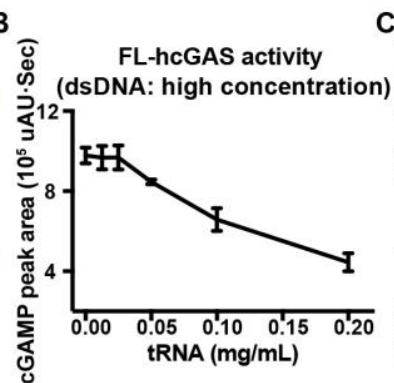

C

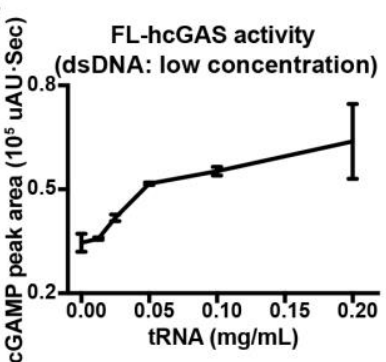

F

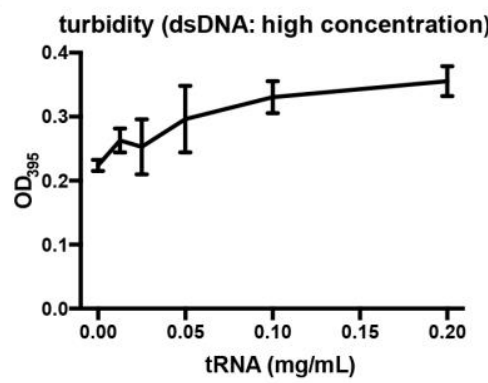

G

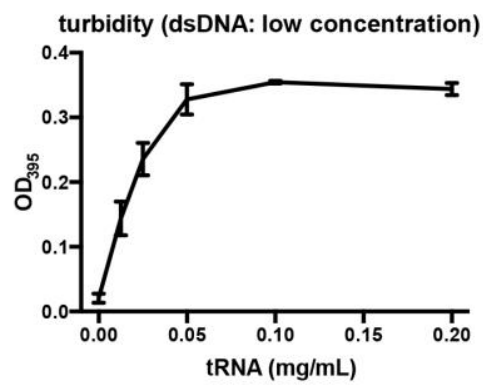

I

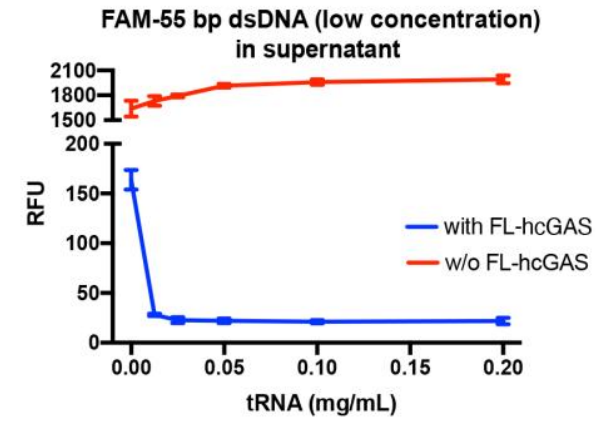


1 Supplemental information for

2

3 Regulation of cGAS activity through RNA-mediated phase separation

4 Silian Chen ${ }^{1 \#}$, Miao Rong ${ }^{1 \#}$, Yun $\mathrm{Lv}^{2}$, Deyu Zhu ${ }^{2 *}$, Ye Xiang ${ }^{1 *}$

$5 \quad{ }^{1}$ Center for Infectious Disease Research, Beijing Frontier Research Center for Biological

6 Structure \& Beijing Advanced Innovation Center for Structural Biology, Department of Basic

7 Medical Sciences, School of Medicine, Tsinghua University, Beijing 100084, China.

$8{ }^{2}$ Department of Biochemistry and Molecular Biology, School of Basic Medical Sciences,

9 Cheeloo College of Medicine, Shandong University, Jinan 250012, China.

$10{ }^{\#}$ Contributed equally to this work.

$11{ }^{*}$ To whom correspondence should be addressed: D.Z.: zhudeyu@sdu.edu.cn, Tel: +86-531-

12 88382092-416; Y.X.: yxiang@mail.tsinghua.edu.cn, Tel: +86-10-62772587 
bioRxiv preprint doi: https://doi org/101101/2020.09 27 316166; this version posted September 28, 2020. The copyright holder for this preprint (which was not certified by peer review) is the author/funder, who has granted bioRxiv a license to display the preprint in perpetuity. It is made available under aCC-BY-NC-ND 4.0 International license.

A

$0.188 \mathrm{mg} / \mathrm{mL}$ FITC-FL-hcGAS + $0.018 \mathrm{mg} / \mathrm{mL}$ ISD

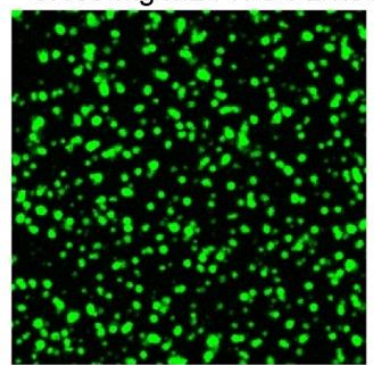

FITC

B

FL-hcGAS $(0.265 \mathrm{mg} / \mathrm{mL})$

ssDNA

$(\mathrm{mg} / \mathrm{mL})$

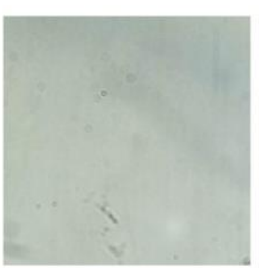

0

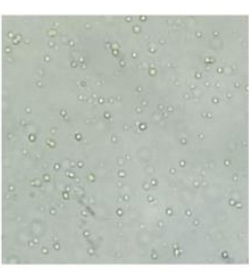

0.011

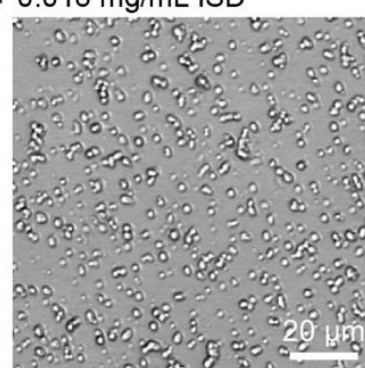

$\mathrm{BF}$

C

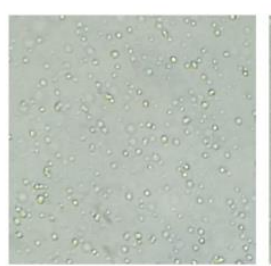

0.028

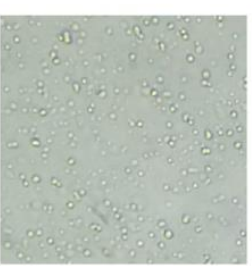

0.054

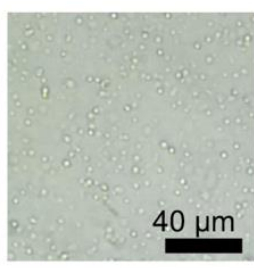

0.111 
Supplemental Figure 1. ssDNA mediates phase separation of FL-hcGAS. A. Fluorescent and bright field photographs showing phase-separated granules of FITC-labeled FL-hcGAS induced by the dsDNA referred to as ISD (for interferon stimulatory DNA), with the sequence 5'TACAGATCTACTAGTGATCTATGACTGATCTGTACATGATCTACA-3’. The FITC-labelled FL-cGAS concentration was $0.188 \mathrm{mg} / \mathrm{mL}$ and the ISD concentration was $0.018 \mathrm{mg} / \mathrm{mL}$.

B. Bright field photographs showing samples of FL-hcGAS $(0.265 \mathrm{mg} / \mathrm{mL})$ and a $48 \mathrm{nt}$ ssDNA at the indicated concentrations.

The 48 nt ssDNA has

the

sequence

$5^{\prime}-$ analysis for the presence of cGAMP, which is indicative of cGAS activation. The FL-hcGAS concentrations was $0.265 \mathrm{mg} / \mathrm{mL}$. ssDNA concentrations were $0.011,0.028,0.054$ and $0.111 \mathrm{mg} / \mathrm{mL}$. NC indicates negative control which has only the FL-hcGAS. The dsDNA ISD was tested at 0.055 and $0.111 \mathrm{mg} / \mathrm{mL}$ as positive controls. Samples were prepared in $20 \mathrm{mM}$ HEPES at $\mathrm{pH} 7.5$ and 150 $\mathrm{mM} \mathrm{NaCl}$. 
bioRxiv preprint doi: https://doi org/101101/2020.09 27.316166; this version posted September 28, 2020. The copyright holder for this preprint (which was not certified by peer review) is the author/funder, who has granted bioRxiv a license to display the preprint in perpetuity. It is made available under aCC-BY-NC-ND 4.0 International license.

A

dsDNA on one side

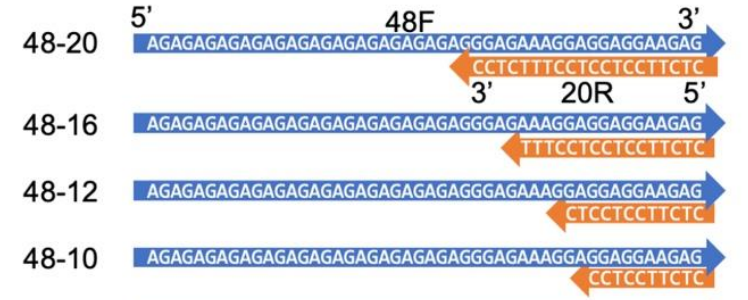

$48-8$

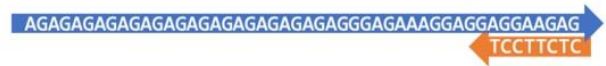

48-6

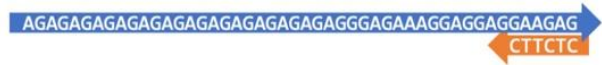

dsDNA in the middle

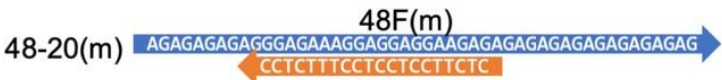

48-16(m) AGAGAGAGAGGGAGAAAGGAGGAGGAAGAGAGAGAGAGAGAGAGAGAG)

48-12(m) AGAGAGAGAGGGAGAAAGGAGGAGGAAGAGAGAGAGAGAGAGAGAGAG)

48-10 $(\mathrm{m})$ AGAGAGAGAGGGAGAAAGGAGGAGGAAGAGAGAGAGAGAGAGAGAGAG
CCTCCTICTC.

48-8(m) AGAGAGAGAGGGAGAAAGGAGGAGGAAGAGAGAGAGAGAGAGAGAGAG)

48-6(m) AGAGAGAGAGGGAGAAAGGAGGAGGAAGAGAGAGAGAGAGAGAGAGAG

B SsDNA control

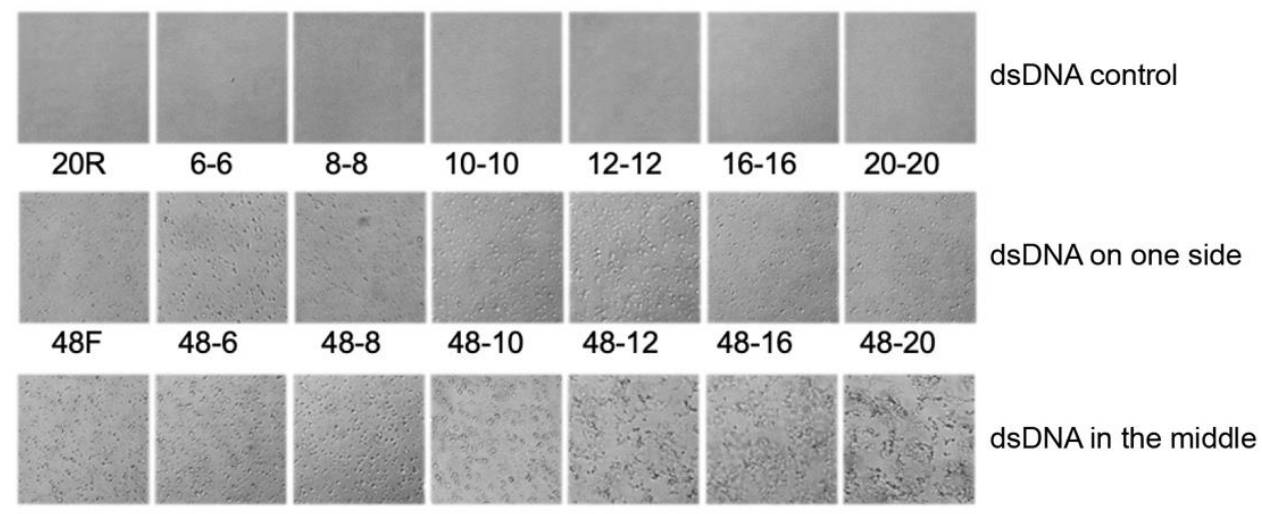

$48 F(m) 48-6(m) 48-8(m) 48-10(m)$ 48-12(m) 48-16(m) 48-20(m)

C

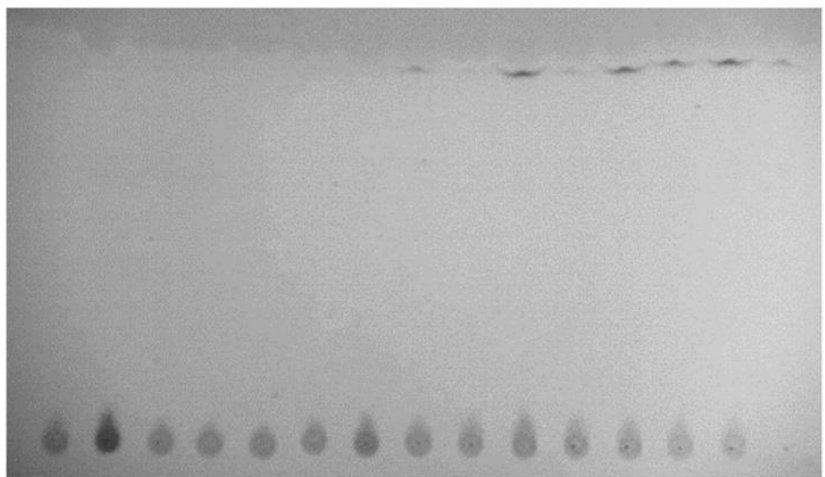

\begin{tabular}{|c|c|}
\hline $20-20$ & $\frac{\text { GGAGAAAGGAGGAGG }}{\text { CCTCTTTCC TCCTCC }}$ \\
\hline $16-16$ & $\begin{array}{l}\text { AAAGGAGGAGGAGAG } \\
T T C C T C C T C C T T C T C\end{array}$ \\
\hline $12-12$ & GAGGAGGAAGAG \\
\hline-10 & $\frac{\text { GGAGGAAGAG }}{\text { CCTCCTICTC }}$ \\
\hline & $\begin{array}{l}\text { AGGAAGAG } \\
\text { TCATCTCTC }\end{array}$ \\
\hline & $\frac{\text { GAAGAG }}{\text { CTICTC }}$ \\
\hline
\end{tabular}


bioRxiv preprint doi: https://doi.org/10.1101/2020.09.27.316166; this version posted September 28, 2020. The copyright holder for this preprint (which was not certified by peer review) is the author/funder, who has granted bioRxiv a license to display the preprint in perpetuity. It is made available under aCC-BY-NC-ND 4.0 International license.

32 Supplemental Figure 2. Short dsDNAs with ssDNA arms promote phase separation and

33 activation of cGAS. A. Sequences of short dsDNAs with ssDNA arms and dsDNA controls. B.

34 Photographs of samples of FL-hcGAS $(0.265 \mathrm{mg} / \mathrm{mL}, 4.4 \mu \mathrm{M})$ with indicated DNAs $(2 \mu \mathrm{M})$ taken with a differential interference contrast microscope. C. TLC analysis for cGAMP, which is indicative of the activation of cGAS, in the presence of short dsDNAs with ssDNA arms. The FL-hcGAS and DNA concentrations were $4.4 \mu \mathrm{M}$ and $2 \mu \mathrm{M}$, respectively. Samples were prepared in $20 \mathrm{mM}$ HEPES at $\mathrm{pH} 7.5$ and $150 \mathrm{mM} \mathrm{NaCl}$. 
bioRxiv preprint doi: https://doi org/10.1101/2020.09.27 316166: this version posted September 28, 2020. The copyright holder for this preprint (which was not certified by peer review) is the author/funder, who has granted bioRxiv a license to display the preprint in perpetuity. It is made available under aCC-BY-NC-ND 4.0 International license.

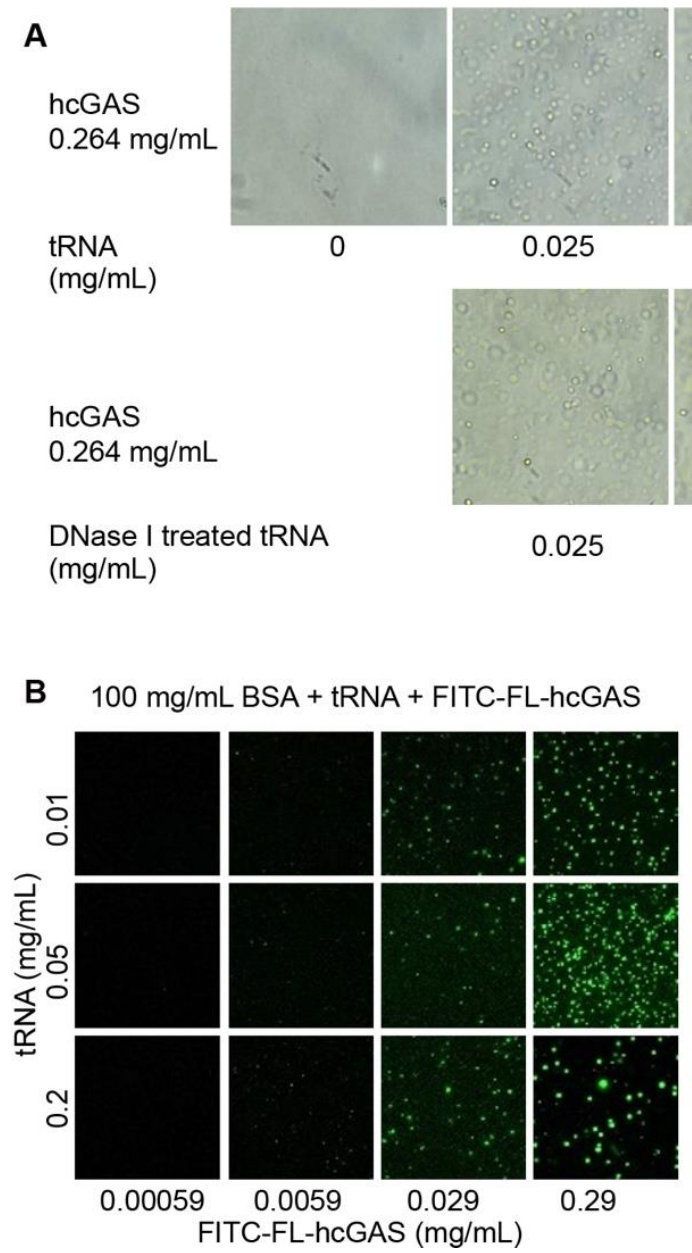


bioRxiv preprint doi: https://doi.org/10.1101/2020.09.27.316166; this version posted September 28, 2020. The copyright holder for this preprint (which was not certified by peer review) is the author/funder, who has granted bioRxiv a license to display the preprint in perpetuity. It is made available under aCC-BY-NC-ND 4.0 International license.

43 Supplemental Figure 3. RNA mediates phase separation of cGAS. A. Upper: Bright field

44 photographs of samples of FL-hcGAS $(0.264 \mathrm{mg} / \mathrm{mL})$ and total RNA from HeLa cells at the indicated

45 concentrations. Lower: Bright field photographs of samples of FL-hcGAS $(0.264 \mathrm{mg} / \mathrm{mL})$ and DNase

46 I-treated total RNA at the indicated concentrations. B. Fluorescent images of FITC-labeled FL-

47 hcGAS and total RNA from HeLa cells in presence of $100 \mathrm{mg} / \mathrm{mL}$ BSA; concentrations of FL-hcGAS and total RNA are indicated. Samples were prepared in $20 \mathrm{mM}$ HEPES, pH 7.5, $150 \mathrm{mM} \mathrm{NaCl}$. 
bioRxiv preprint doi: https://doi.org/10.1101/2020.09.27.316166; this version posted September 28, 2020. The copyright holder for this preprint (which was not certified by peer review) is the author/funder, who has granted bioRxiv a license to display the preprint in perpetuity. It is made available under aCC-BY-NC-ND 4.0 International license.

A

cGAS $(\mu \mathrm{M})$

\section{FL-hcGAS}

\section{hcGAS-CTD}

hcGAS-NTD

동

F⿻上丨

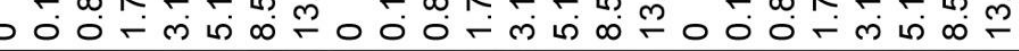

ISD

$10 \mu \mathrm{g} / \mathrm{mL}$

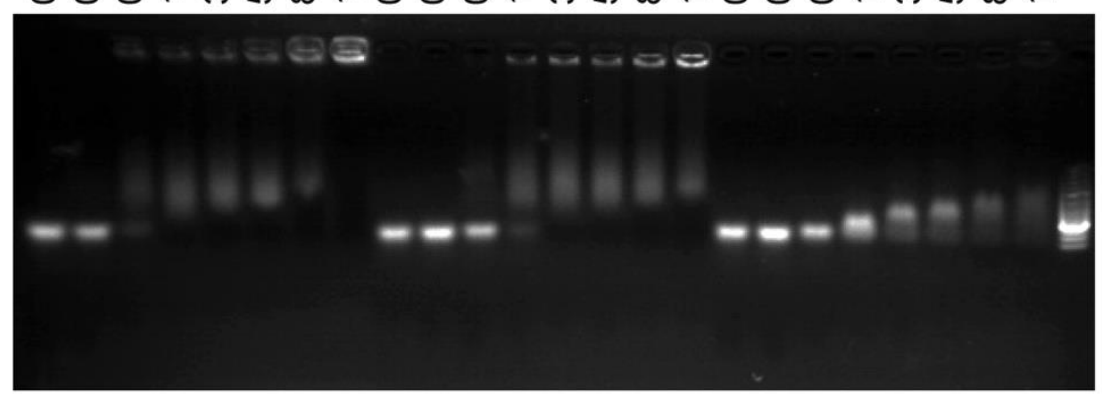

B

$380 \mathrm{bp}$

dsDNA

$10 \mu \mathrm{g} / \mathrm{mL}$

\section{FL-hcGAS}

\section{hcGAS-CTD}

hcGAS-NTD

cGAS $(\mu \mathrm{M})$

N

N

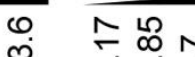

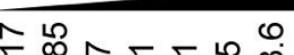
○ 00

C

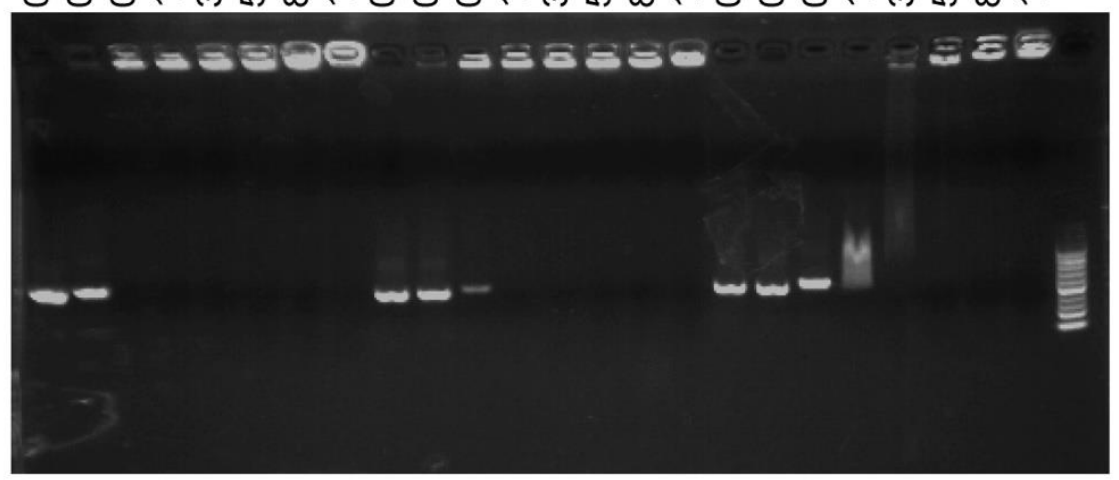

cGAS $(\mu \mathrm{M})$

FL-hcGAS

hcGAS-CTD

hcGAS-NTD

둥

o 00 m

tRNA

$10 \mu \mathrm{g} / \mathrm{mL}$

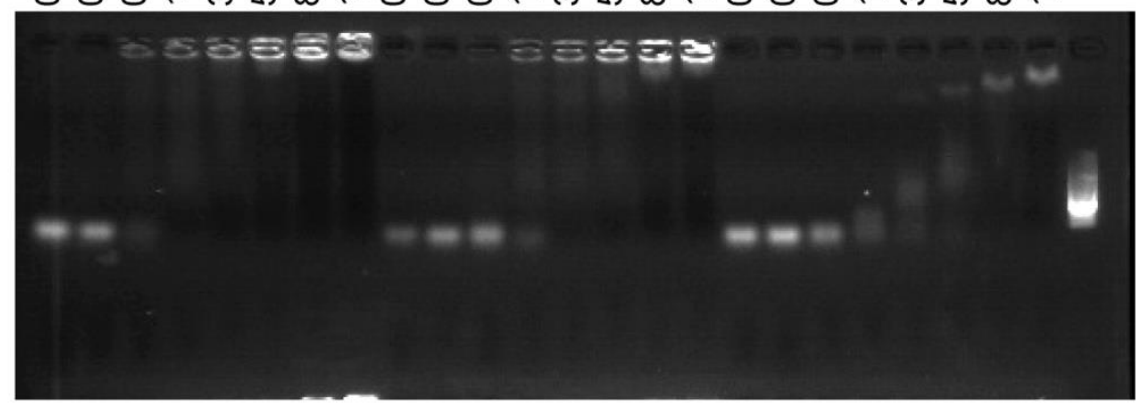

D

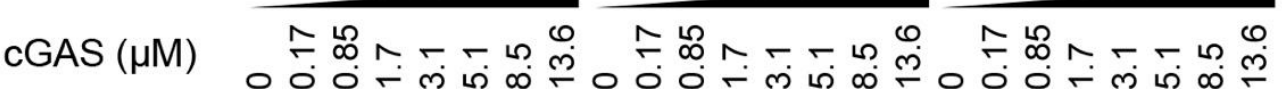

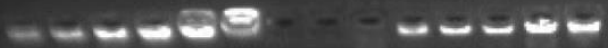

ssRNA

$10 \mu \mathrm{g} / \mathrm{mL}$ 
bioRxiv preprint doi: https://doi.org/10.1101/2020.09.27.316166; this version posted September 28, 2020. The copyright holder for this preprint (which was not certified by peer review) is the author/funder, who has granted bioRxiv a license to display the preprint in perpetuity. It is made available under aCC-BY-NC-ND 4.0 International license.

51 Supplemental Figure 4. RNA and DNA bind cGAS with similar affinity. Electrophoretic mobility

52 shift analysis of ISD, 380-bp dsDNA, yeast tRNA and ssRNA in presence of FL-hcGAS. The nucleic

53 acid concentration was $10 \mathrm{ng} / \mu \mathrm{L}$. The cGAS concentrations were $0,0.17,0.85,1.7,3.4,5.1,8.5$, and

$54 \quad 13.6 \mu \mathrm{M}$.

55

56 

bioRxiv preprint doi: https://doi.org/10.1101/2020.09.27.316166; this version posted September 28, 2020. The copyright holder for this preprint (which was not certified by peer review) is the author/funder, who has granted bioRxiv a license to display the preprint in perpetuity. It is made available under aCC-BY-NC-ND 4.0 International license.

59 Supplemental Figure 5. Hoechst 33342 and pyronin $Y$ differentially stain dsDNA and RNA in

60 the cGAS involved phase separations. Confocal microscopy images of FL-hcGAS incubated with

61 55-bp dsDNA, total RNA from HeLa cells, or yeast tRNA and stained with $2 \mu \mathrm{g} / \mathrm{mL}$ Hoechst 33342

62 and $4 \mu \mathrm{g} / \mathrm{mL}$ pyronin $\mathrm{Y}$. The FL-hcGAS concentrations was $0.2 \mathrm{mg} / \mathrm{mL}$. 55-bp dsDNA, total RNA

63 and yeast tRNA concentrations were both $0.1 \mathrm{mg} / \mathrm{mL}$.

64 
bioRxiv preprint doi: https://doi.org/10.1101/2020.09.27.316166; this version posted September 28, 2020. The copyright holder for this preprint (which was not certified by peer review) is the author/funder, who has granted bioRxiv a license to display the preprint in perpetuity. It is made available under aCC-BY-NC-ND 4.0 International license.

65

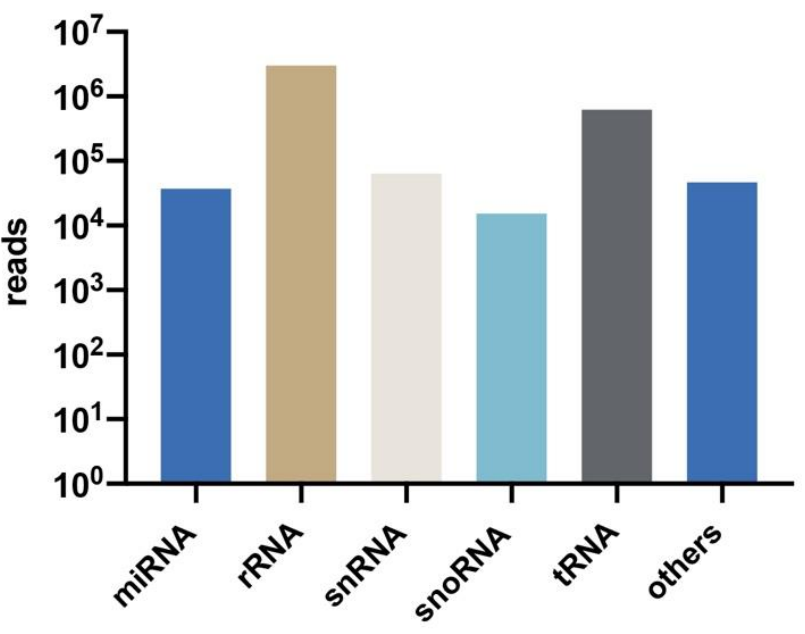

66 
bioRxiv preprint doi: https://doi.org/10.1101/2020.09.27.316166; this version posted September $28,2020$. The copyright holder for this preprint (which was not certified by peer review) is the author/funder, who has granted bioRxiv a license to display the preprint in perpetuity. It is made available under aCC-BY-NC-ND 4.0 International license.

Supplemental Figure 6. Sequencing of RNA in the cGAS-containing fraction from cytoplasm.

69 Two libraries were generated from band 5 from the Opti-prep gradient: one for non-coding RNA and

70 one for mRNA sequencing. The histograms show the numbers of non-coding RNA sequencing reads.

71 mRNA was also sequenced and the results showed coverage of most of the actively transcript genes. 
bioRxiv preprint doi: https://doi.org/10.1101/2020.09.27.316166; this version posted September 28, 2020. The copyright holder for this preprint (which was not certified by peer review) is the author/funder, who has granted bioRxiv a license to display the preprint in perpetuity. It is made available under aCC-BY-NC-ND 4.0 International license.

A

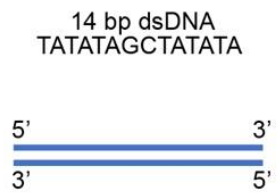

B
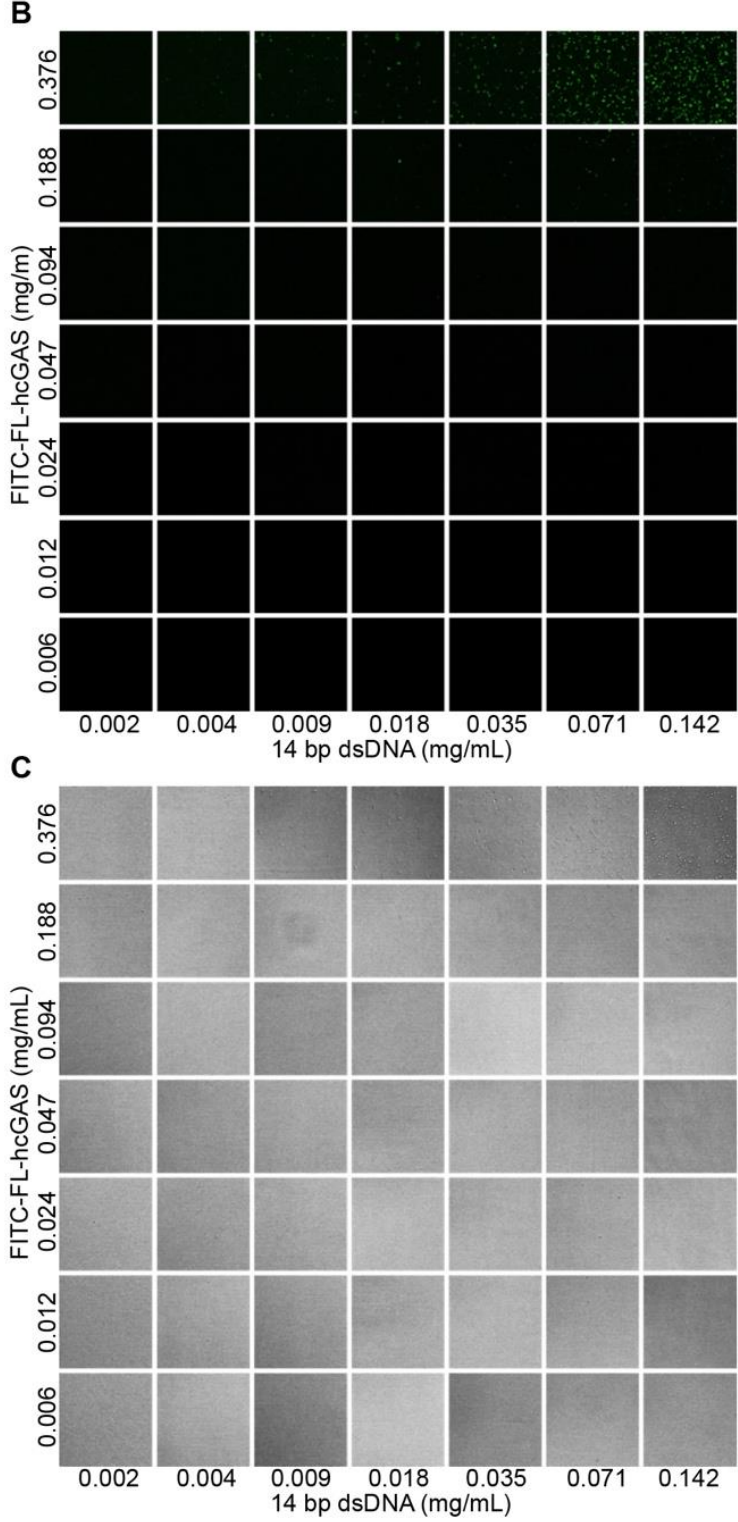

Y-form DNA

20 bp dsDNA
GGGTATATAGCTATATACCC

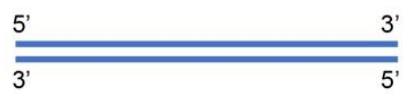

D
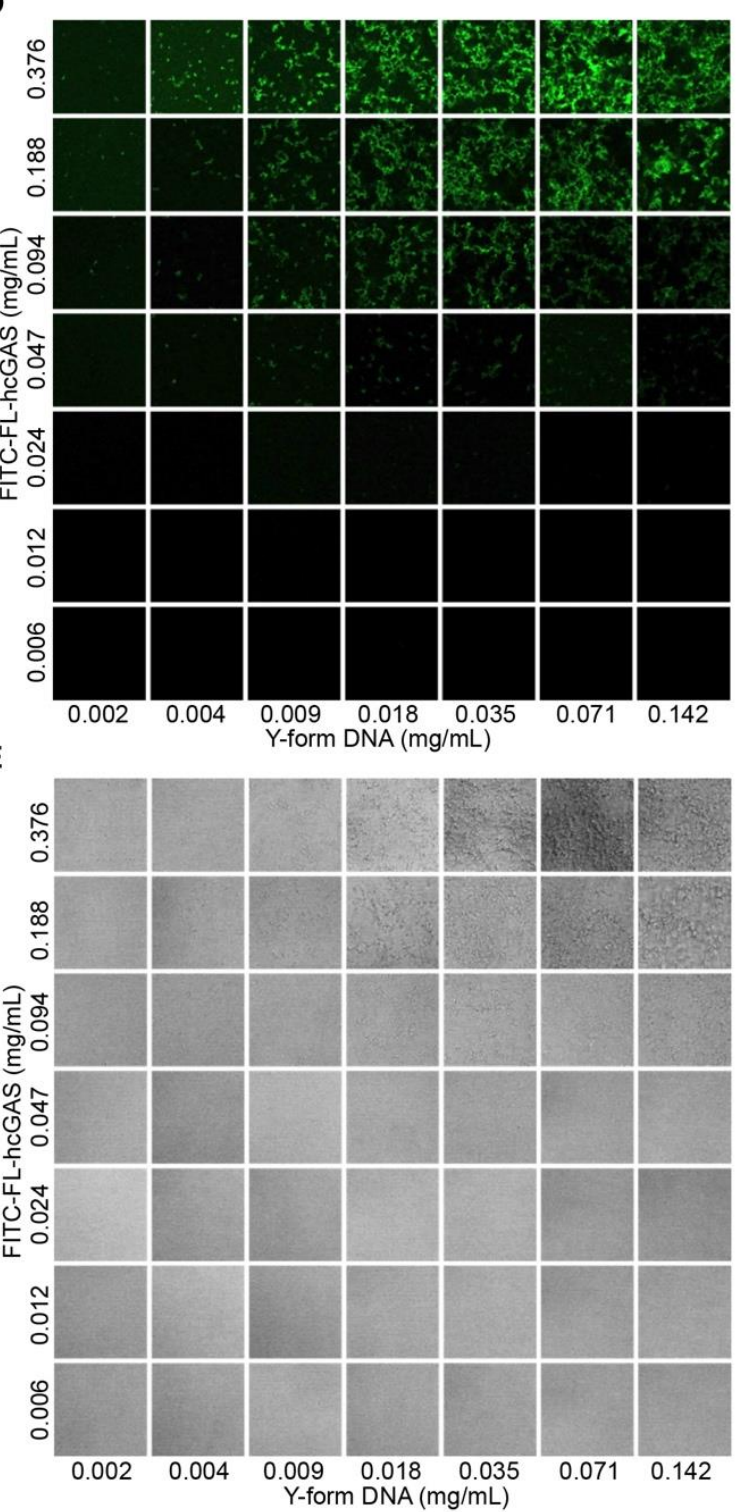
Supplemental Figure 7. Y-form DNA and 14-bp dsDNA mediate phase separation of FL-hcGAS.

A. Sequences and structures of the, 14-bp dsDNA, 20-bp dsDNA and Y-form DNA. B. Fluorescent images of samples of FITC-FL-hcGAS and the 14-bp dsDNA at indicated concentrations. C. Corresponding bright field photographs of samples of FITC-FL-hcGAS and the 14-bp dsDNA at indicated concentrations. D. Fluorescent images of samples of FITC-FL-hcGAS and the Y-form DNA at indicated concentrations. E. Corresponding bright field photographs of samples of FITC-FLhcGAS and the Y-form DNA. 


\section{fluorescence-concentration correlation}

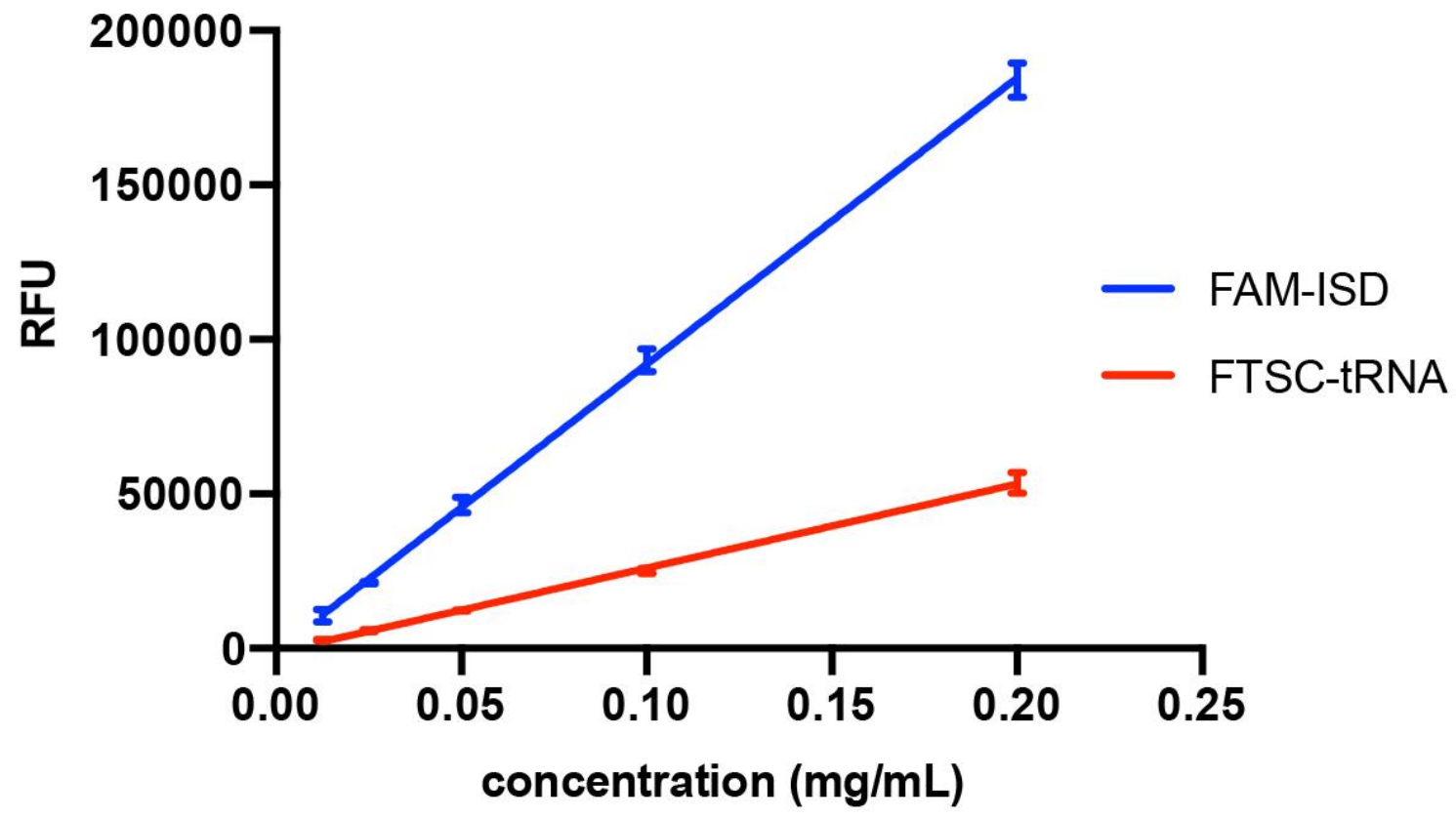


bioRxiv preprint doi: https://doi.org/10.1101/2020.09.27.316166; this version posted September 28, 2020. The copyright holder for this preprint (which was not certified by peer review) is the author/funder, who has granted bioRxiv a license to display the preprint in perpetuity. It is made available under aCC-BY-NC-ND 4.0 International license.

87 Supplemental Figure 8. Correlation of fluorescence signal (RFU) with concentration for 88 fluorophore labeled ISD and tRNA. 